LESZEK DRONG

University of Silesia in Katowice

e-mail: drong@us.edu.pl

\title{
Between Innovation and Iteration: Post-Joycean Heteroglossia in Eimear McBride's A Girl Is a Half-formed Thing
}

\begin{abstract}
Eimear McBride's A Girl Is a Half-formed Thing (2013) is a prime specimen of post-Joycean heteroglossia in Irish fiction. The novel exhibits a programmatic dialogical/intertextual orientation orchestrated with its own parodic and ironic modes, which makes McBride's work uniquely capable of re-energizing Irish cultural tradition. Simultaneously, her novel contributes its own distinct voice to the impressive amplitude of artistic expressions which have emerged from Irish culture in the wake of Joyce's writings. Mikhail Bahtin's approach to the novel (as discussed in The Dialogic Imagination), in turn, is particularly relevant to McBride's fiction because of her incorporation (as well as adaptation) of a variety of voices and perspectives. As a consequence, in A Girl Is a Half-formed Thing, the categories of heteroglossia and dialogism appear to be responsible for creating and sustaining a vital cultural dimension, a dimension which is subject to being perpetually rewritten in the present, even though it crucially depends upon ur-texts from the past.
\end{abstract}

Keywords: McBride, heteroglossia, intertextuality, dialogism, realism, parody, irony, Irish novel, Bakhtin, Joyce.

As a polyphonic text, Eimear McBride's debut novel, A Girl Is a Half-formed Thing, resonates with earlier Irish writings and yet it is also capable of speaking with its own sonorous voice. Crucially, its intertextual dimension does not paralyze its originality. My aim here is to demonstrate how McBride attains that originality by striking a balance (while simultaneously creating a deliberate tension) between assimilating her predecessors (most notably Joyce, but also a host of others) and maintaining a critical distance on their writings, which often finds its manifestation in the exercise of parody and irony. Given A Girl Is a Half-formed Thing's polyphonic quality, I find Mikhail Bakhtin's categories of heteroglossia and dialogism particularly relevant to my argument. It is worth bearing in mind that the original and most fundamental meaning of intertextuality introduced by 
Julia Kristeva in 1966 was meant as a mere synonym for Bakhtin's dialogism, or his understanding of communication. ${ }^{1}$ As a consequence, without collapsing the subtle semantic distinctions between heteroglossia, dialogism and intertextuality I focus on what they share in order to see how, in McBride's novel, respect for the past and for literary heritage is in permanent conflict with a desire to express new messages in a new idiom.

Perhaps "conflict" is too strong a word to describe the polyphonic tension within A Girl is a Half-formed Thing. In Bakhtin's view, there is nothing unusual about that kind of heterogeneity; in fact, what he rejects is also an essentialist unitary conception of the self. ${ }^{2}$ That is why he assumes that characters in the novel internalize and express various intentions in different languages: the original definition of heteroglossia, which Bakhtin offers in The Dialogic Imagination, posits characters as vehicles not just for their own intentions but also for refracted intentions of their authors. ${ }^{3}$ In a more general sense, heteroglossia (Russian разноречие; literally, different speeches or voices) implies a discursive phenomenon practically identical to the fundamental concepts of intertextuality developed in the late 1960's and 1970's. Simultaneously, the internal dialogism of the word, which Bakhtin postulates, involves, among other things, a future orientation in the sense that "every word is directed toward an answer and cannot escape the profound influence of the answering word that it anticipates". ${ }^{4}$ The effect of this anticipation is that the internally dialogized word is always influenced by the words to come, by an answer that has not yet occurred. In other words, Bakhtin assumes the possibility of reconfiguring the meaning of the past by the future. Clearly, a view like that has much in common with T. S. Eliot's notion of tradition, expounded in his essay "Tradition and the Individual Talent". Eliot also believes that "the supervention of novelty" in the existing order of the monuments of past art is eventually capable of altering the order. ${ }^{5}$ But it is Bakhtin who offers an in-depth philosophical and linguistic analysis of those issues in his writings, especially in "Discourse in the Novel", where, in contrast to Eliot, who idolizes poetry, he attaches particular significance to the genre of the novel, or what he variously calls "artistic prose" and "novelistic discourse". ${ }^{6}$ Only there does language's dialogic quality transpire; only there can heteroglossia unfurl its multivocal splendor.

A Girl is a Half-formed Thing by Eimear McBride was published in 2013 although, according to its author, it was written much earlier, between 2003 and

1 See J. Kristeva, Desire in Language: A Semiotic Approach to Literature and Art, ed. L.S. Roudiez, transl. Th. Gora, A. Jardine, L.S. Roudiez, New York 1980, p. 68.

2 See M.J. Martinez Alfaro, Intertextuality: Origins and Development of the Concept, "Atlantis" 1996, vol. 18, no. 1/2, p. 273.

3 See M.M. Bakhtin, The Dialogic Imagination: Four Essays, ed. M. Holquist, transl. C. Emerson, M. Holquist, Austin 1981, p. 324.

${ }^{4}$ Ibid., p. 280.

5 See T.S. Eliot, Tradition and the Individual Talent [in:] T.S. Eliot, The Sacred Wood: Essays on Poetry and Criticism, New York 1921, p. 44-45.

6 M.M. Bakhtin, op. cit., p. 269. 
2004. ${ }^{7}$ McBride's first novel, while clearly indebted to Irish, British and continental masters, was so disturbingly innovative and daring that it took almost ten years to find a discerning publisher. Once it came out, it became an instant success, largely because of its uncompromising willingness to address many social taboos in Ireland. What may seem striking about the novel's plot and non-conformist language, which at some points reads like "visceral poetry", is that they depend on the patterns that McBride seeks to subvert, censure and rewrite. Also, in interviews, she plainly acknowledges having been inspired by James Joyce, Lars von Trier and Sarah Kane. ${ }^{9}$ As a narrative of self, focused on birth, maturation, education, adolescence, sexual repression, abuse, rape, release of pent-up emotions, confrontation with death (first her grandpa and then her brother), and finally suicide, A Girl is, in many respects, a classical Bildungsroman written in a style which is reminiscent of the stream-of-consciousness technique, and which McBride herself describes as "stream-of-existence". ${ }^{10}$ Her unnamed protagonist/ narrator is both a passive victim of Irish society and a vocal prosecutor by dint of remaining half way between body and language, reality and fiction.

McBride's novel consistently upholds the principles of dialogism by fulfilling, on the one hand, all the basic criteria of the Bildungsroman and, on the other, by engaging in a mode of social criticism, its characters hinting at the possession of what Astrid Erll calls "collective-autobiographical memory". ${ }^{11}$ Thereby those characters can be read as both unique and representative of social groups or entire generations because "through collective-autobiographical acts of memory, group identities are created, the experience of time is culturally shaped, and shared systems of values and norms are established". ${ }^{12}$ Recent Irish novels - e.g. Reading in the Dark by Seamus Deane, The Secret Scripture and The Temporary Gentleman by Sebastian Barry, The Little Red Chairs by Edna O'Brien - provide ample evidence that post-Joycean fiction deploys realism to make larger (i.e. supra-individual) historical and/or political claims. Although the (cultural/ literary) past is usually challenged, censured or, possibly, exposed to ridicule in many of the writings which parade their post-Joycean heteroglossia, it is still there, as a necessary point of reference, a solid rock to build its contemporary critique on. Liam Harte, in his discussion of contemporary Irish novels, insists that what distinguishes those writings from the prose published forty years earlier

7 See E. McBride, How I Wrote A Girl Is a Half-formed Thing, "The Guardian", 10 Sep 2016, https:/www.theguardian.com/books/2016/sep/10/guardian-book-club-eimear-mcbride-how-i-wrotea-girl-is-a-half-formed-thing (access: 08.09.2017).

8 A. Fogarty, "It was Like a Baby Crying": Representations of the Child in Contemporary Irish Fiction, "Journal of Irish Studies" 2015, vol. 30, p. 22.

${ }^{9}$ See E. McBride, How I Wrote... (access: 08.09.2017). There are obviously more acknowledged and unacknowledged inspirations in the novel. I discuss some of those further on this essay but here my point is that to laud McBride's debut as a clean break with the tradition of the Irish novel is to miss its point.

${ }^{10}$ Ibid. (access: 08.09.2017).

11 A. Erll, Memory in Culture, London 2009, p. 105.

12 Ibid., p. 106. 
is a sense of delivery from the anxiety of Joyce's stifling influence; instead, for contemporary novelists, Joyce's oeuvre finally becomes inspiring and liberating. ${ }^{13}$

In one of the most enthusiastic reviews of $A$ Girl Is a Half-formed Thing, Anne Enright identifies Eimear McBride as not less than a genius. Interestingly, Enright uses the word in collocation with the adjective "old-fashioned". In her opinion, "Eimear McBride is that old fashioned thing, a genius, in that she writes truth-spilling, uncompromising and brilliant prose that can be, on occasion, quite hard to read". ${ }^{14}$ The latter part of Enright's sentence smuggles in an ambiguous compliment, still, when it comes to masterpieces of Irish literature, opacity seems to have been a sine qua non at least since Joyce. In McBride's case, her genius lies in being old-fashioned and subversive at the same time: her Girl speaks the language of Molly Bloom but her idiom is ironically inflected. Molly's conclusive "Yes" from the final page of Ulysses meets with a resounding "No" (or "not at all") in Girl's parodic monologue:

I met a man. I met a man. I let him throw me round the bed. And smoked, me, spliffs and choked my neck until I said I was dead. I met a man who took me for walks. Long ones in the country. I offer up. I offer up in the hedge. I met a man I met with her. She and me and his friend to bars at night and drink champagne and bought me chips at every teatime. I met a man with condoms in his pockets. Don't use them. He loves children in his heart. No. I met a man who knew me once. Who saw me around when I was a child. Who said you're fine looking woman now. Who said come back marry me live on my farm. No. I met a man who was a priest I didn't I did. Just as well as many another one would. I met a man. I met a man. Who said he'd pay me by the month. Who said he'd keep me up in style and I'd be waiting when he arrived. No is what I say. I met a man who hit me a smack. I met a man who cracked my arm. I met a man who said what are you doing so late at night. I met a man. I met a man. And wash my mouth out with soap. I wish I could. That I did then. I met a man. A stupid thing. I met a man. Should have turned on my heel. I thought. I didn't know to think. I didn't even know to speak. I met a man. And I lay down. And slapped and cried and wined and dined. I met a man and many more and didn't know you at all. ${ }^{15}$

This is an almost unique passage in the novel in that it is made up of several full-fledged sentences. Its poetic quality, skilfully accentuated by the use of anaphora, ironically clashes with the brutality and triviality of some of Girl's sexual experiences. This is as close as McBride's prose gets to the representation of the "flow" of consciousness; otherwise, as John Sutherland notes, although there are clear stylistic affinities there with modernist writers (Beckett comes to mind most readily), "McBride, unlike, say, Virginia Woolf in Mrs Dalloway, offers nothing that 'flows' - there's no 'stream', as such". ${ }^{16}$ To put it in a postmodern

13 See L. Harte, Reading the Contemporary Irish Novel 1987-2007, Chichester 2014, p. 16.

14 A. Enright, A Girl Is a Half-Formed Thing by Eimear McBride, Review, "The Guardian", 20 Sep 2013, https://www.theguardian.com/books/2013/sep/20/girl-half-formed-thing-review (access: 08.09.2017).

15 E. McBride, A Girl is a Half-formed Thing, London 2014, p. 96-97.

16 J. Sutherland, Eimear McBride's Novel Doesn't Fit any Terms We Use to Categorise Writing, "The Guardian", 6 Jun 2014, https://www.theguardian.com/commentisfree/2014/jun/06/eimear-mcbride-novel-terms-writing-consciousness (access: 08.09.2017). 
idiom, what she offers is repetition with a difference, a repetition that requires a creative remembering of literary tradition.

Rather perplexingly, McBride's strategies of remembering and "disremembering" her predecessors are virtually impossible to disentangle. Girl may want to fly through the nets of family, the church, the nation and the patriarchal, chauvinistic community which tries to "form" her and yet her every gesture is caught in a relational web of meanings, predefined by prior matrices of defiance and rebellion. McBride's protagonist immerses herself in those intertextual allusions, like in the lake episode when Girl has an epiphany, a mirror experience to Stephen Dedalus's vision of the bird-like girl towards the end of Chapter 4 of A Portrait of the Artist as a Young Man. In fact, McBride's Girl resembles Joyce's wading girl from A Portrait; the key difference is that there is no Stephen in the picture. Girl is alone and trying to pray:

Come running by the lake. Fall down. I am almost too old for that I should be smoking drinking now. Taking hands up my jumper. Fingers down my skirt. I should be. I should be. I am not. Yet. (...) That flock of geese is rising. Rising to make all the noises. Honk like cars and wings beat hard on the air. Battering it. Cutting it down. They are going up and up. Feathers and fat young breasts rise and rise above me. I see. I see clear. (...) I sink baptize me now oh lord and take this bloody itch away for what I am I the wrong and wrong of it always always far from thee. ${ }^{17}$

What she emphasizes in the self-description is her distance from the birds and the sky/heaven; she is unlike air-borne creatures ${ }^{18}$, doomed to be alienated from her maker because of some ontological flaw. And yet she performs the rite of baptism, entrusting herself to water, which will eventually prove to be her grave as well. On a number of occasions in her narrative, Girl will seek the recuperative fluidity of the lake in an attempt to restore equilibrium to her existence.

Parallels with A Portrait seem to be obvious also on the level of language and yet they are complex and far from imitative. McBride's polemical use of intertextuality is evident at the very beginning when Girl is still in the womb, and her gestation is logically incommensurate with the discourse that she is capable of producing. Unlike Stephen, who does not claim the reader's attention until he becomes articulate (Joyce's novel is written in free indirect speech), McBride's protagonist maintains the same degree of linguistic competence throughout the narrative. Like Stephen, she is never at home in English ${ }^{19}$, her syntax always half-formed, sentences unfinished, the novel as such like a literary amnion, which protects a foetus (another critically important word in A Portrait by Joyce), still too vulnerable for the confrontation with the outside world. There is also much to the juxtapositions with William Butler Yeats, Samuel Beckett ${ }^{20}$, John Banville and Edna O'Brien, but in the final analysis McBride's fiction speaks with its own

17 E. McBride, A Girl is a Half-formed Thing..., p. 54-55.

18 Joyce's epiphany from A Portrait is in many respects inverted and demystified here. The birds in Girl's description are like Icarus soaring into the sky. There is no inspiration for anybody. God does not answer, either.

19 See A. Fogarty, op. cit., p. 22.

20 See A. Enright, op. cit. 
voice against society, tradition, the Catholic Church and all the culturally determined modes of prescribing identity in Ireland. The novel itself remembers more than just Irish literary history. That is why Bakhtin's description of Rabelais's style seems to be remarkably relevant here. McBride's protagonist is also "afraid to entangle herself in the word, to soil herself in verbal pathos". ${ }^{21}$ Apropos of pathos and parody, Bakhtin notes that "Rabelais taunts the deceptive human word by a parodic destruction of syntactic structures, thereby reducing to absurdity some of the logical and expressively accented aspects of words (for example, predication, explanations and so forth)". ${ }^{22}$ The purity of McBride's prose is jeopardized only by the polyphony of traditions and discourses that inhabit her work but the ironic and parodic distance that her narrator maintains delivers Girl from being diluted, so to speak, as a protagonist.

If McBride is indeed a genius, it is because she is never inclined to imitate but then neither is she tempted to simply invert recognized patterns. Girl, again like Joyce's Stephen (who, e.g., modifies the meaning of epiphany to suit his artistic needs), osmotically absorbs religious discourse without accepting the principles that arise from the teachings of the Catholic Church. By gradually secularizing some of it, and eventually identifying the rite of baptism with her own suicide, Girl radicalizes Joyce's discursive strategy. Some of her initial prayers may intuitively be addressed to God but towards the end of the novel she kneels by the side of her dying brother's bed and prays to her brother ("And I genuflect your quiet bed"23). Stephen Dedalus refuses to pray for his dying mother; McBride's protagonist confounds the cultural and symbolic codes of Christianity by ostensibly following them and yet her blasphemy seems to require more imagination and courage than Stephen's straightforward defiance. After her brother's death her account of immersion in the lake is still interspersed with a second-person narrative in which Girl seeks to reunite with the brother. Her suicide in water is construed as a homecoming although the manner in which the lake is described has little to do with purity and a new life: "Swim. See my scrawl there. Under my feet. Mud among the reeds where the ripple fish go. And vomit and some half drunk can, some things, some paper bags some cigarette rolled and stuffed and smoked. Ground to the heel. This home I know". ${ }^{24}$ For ultimate purification, for washing away the world as she knows it, Girl has to immerse herself completely and return to the very beginning, to the state of absolute innocence: "Go out. Go out further where the water is fine. On my bare legs. On my thighs. Knowing what I am. Come the. Still. My. Slipping over my hips and stomach. On my mind. Through fingers combing there. Soak in my white shirt colder. Up the spine. Duck it duck now or I'll never go in. The brown foam. Baptise". ${ }^{25}$ The baptism is ironically represented here as a shedding of her name, which, by the way, has never been disclosed to the reader. Unlike with most protagonists of twentieth-century

21 M.M. Bakhtin, op. cit., p. 309.

22 Ibid., p. 309.

23 McBride, A Girl is a Half-formed Thing..., p. 171.

24 Ibid., p. 201.

25 Ibid., p. 201. 
Bildungsromane, who grow up to achieve great things and become important figures, in her conclusion, McBride kills Girl with a metonymy; the last sentence of her novel reads: "My name is gone". ${ }^{26}$

What is crucial about McBride's reliance on various parodic and ironic modes is that, simultaneously, she never relinquishes the advantages of realism. As a consequence, the sort of realism she favours is always already post-Joycean: internally conflicted, dialogized, in permanent tension with those literary strategies that seem to go against its grain. The realism of her novel is a well-wrought literary convention which builds upon several ages of cultural tradition and yet, by involving a variety of distancing devices typical of postmodern fiction, it also poses an interpretive challenge to those who see in her writing a crooked reflection (a refraction? a parallax?) of Irish reality. Without being imitative, A Girl is a Half-formed Thing recognizes the value of the past, absorbs both its history and its fictions, and eventually transforms and rewrites what is left of the urtexts by its great predecessors. The novel's heteroglossia and polyphony testify to McBride's eloquence as a contemporary writer, a Joycean god of the creation, who can still afford to let others speak in her text while she "remains within or behind or beyond or above [her] handiwork, invisible, refined out of existence, indifferent, paring [her] fingernails ". ${ }^{27}$ Although the ironic distance she assumes in the novel may imply that she is concealing some nostalgia for a paradise lost, for the primordial innocence of a Ulyssesless unitary universe, her message seems to be that it is much easier to be a godlike artist by following in the footsteps of "a priest of eternal imagination". 28

\section{Bibliography}

Bakhtin M.M., The Dialogic Imagination: Four Essays, ed. M. Holquist, transl. C. Emerson, M. Holquist, Austin 1981.

Eliot T.S., Tradition and the Individual Talent [in:] T.S. Eliot, The Sacred Wood: Essays on Poetry and Criticism, New York 1921.

Enright A., A Girl Is a Half-Formed Thing by Eimear McBride, Review, The Guardian”, 20 Sep 2013, https://www.theguardian.com/books/2013/sep/20/girl-half-formed-thing-review (access: 08.09.2017).

Erll A., Memory in Culture, London 2009.

Fogarty A., "It was Like a Baby Crying": Representations of the Child in Contemporary Irish Fiction", "Journal of Irish Studies" 2015, vol. 30, p. 13-26.

Harte L., Reading the Contemporary Irish Novel 1987-2007, Chichester 2014.

Joyce J., A Portrait of the Artist as Young Man [in:] J. Joyce, The Essential James Joyce, London 1991.

Kristeva J., Desire in Language: A Semiotic Approach to Literature and Art, ed. L.S. Roudiez, transl. Th. Gora, A. Jardine, L.S. Roudiez, New York 1980.

26 Ibid., p. 203.

27 J. Joyce, A Portrait of the Artist as Young Man [in:] J. Joyce, The Essential James Joyce, London 1991, p. 397.

28 Ibid., p. 403. 
Martinez Alfaro M.J., Intertextuality: Origins and Development of the Concept, "Atlantis" 1996, vol. 18, no. 1/2, p. 268-285.

McBride E., A Girl is a Half-formed Thing, London 2014.

McBride E., How I Wrote A Girl Is a Half-formed Thing, "The Guardian”, 10 Sep 2016, https://www.theguardian.com/books/2016/sep/10/guardian-book-club-eimearmcbride-how-i-wrote-a-girl-is-a-half-formed-thing (access: 08.09.2017).

Sutherland J., Eimear McBride's Novel Doesn't Fit any Terms We Use to Categorise Writing, "The Guardian", 6 Jun 2014, https://www.theguardian.com/commentisfree/2014/jun/06/eimear-mcbride-novel-terms-writing-consciousness (access: 08.09.2017). 